\title{
Electro-deposition paint. II.
}

UDC

$667.634 .4^{\prime} 12.087$

$667.633 .263 .3: 678$.

$643: 678.632-19$

\author{
Minara Kazuyuki and Yukuta Tateki \\ Tokyo Laboratory, Osaka wanisu Co., Ltd.*
}

\begin{abstract}
Phosphoric acid ester of fatty acid-modified epoxy resin, which can be obtained by the esterification of epoxy resin with fatty acid in the flrst step and then with phosphoric acid, becomes a resin for use of paint which is perfectly emulsifiable in the water when the ester is neutralized with organic amine. An even coated fllm of the resin can be separated out on the surface of metal products when the metal piece immersed into aqueous dispersion of the resin is put on electric circuit by connecting the metal piece being cathod and iron piece being anode and with direct current of $30 \sim 60$ volt.

Authors investigated the composition and the conditions of the resin for coating by means of electrophoresis. In this report, the authors used an epoxy resin of epichlorohydrin-diphenylolpropane type (Epikote \# 834, of Shell Chemical). As the fatty acid for esterification, lauric acid, palmitic acid, stearic acid, oleic acid, linolic acid and fatty acid of dehydrated castor oil, etc were selected, and each one mol of the fatty acid was used for one mol of epoxy resin for esterification, and subsequent estrification was made with one mol of phosphoric acid. Thus prepared ester was neutralized with triethanolamine and was dispersed into water so as the nonvolatile matter becomes 10\%. Thus obtained emulsion was investigated for difference of electro-deposition property to be caused by the kind of fatty acid, and for characteristic of the film after dried. And additional investigation was made for the water soluble phenol resin to be used linking agent of the phosphoric acid ester of fatty acid-modified epoxy resin, thus prepared, in order to make clear that the phenolic resin merely mixed at a constant ratio into the emulsified aqueous solution of resin thus synthesized would be found in the electro-deposited film at the same mixed ratio as compared with that before coating. Upon experiments the following facts were made clear by the authors.

1) As for the fatty acid, the oleic acid, linolic acid and fatty acid of dehydrated castor oil, each of which is unsaturated fatty acid 18 of carbon numbers, were superior.

2) In this synthesized product, the ratio of water soluble phenolic resin to the emulsified aqueous solution, at any optional mixing ratio, was approximately the same with that ratio contained in the electro-deposited film, and which was confiemed from $\log I_{0} / I\left(1500 \mathrm{~cm}^{-1}, 810 \mathrm{~cm}^{-1}\right)$ of infrared spectrum for the coated film separated out.

3) The electro-deposited film, which was prepared from phosphoric acid ester of linolic acid-modified epoxy resin by the neutralization with triethanolamine and then by mixing thereinto with $4-5$ parts of water soluble phenolic resin to the 5-6 parts of thus neutralized product, was stable against boiling water for more than 50 hours.
\end{abstract}

* 4-1-8 Kamata, Oota-ku, Tokyo, Japan. 


\section{電着用塗料に関する研究（第 2 報）}

UDC

$667.634 .4^{\prime} 12.087$

$667.633 .263 .3: 678$

$643: 678.632-19$

$$
\text { 三原一幸**・行 田干城** }
$$

要 旨

脂肪酸変性エポキシ樹脂リン酸エステルによる電着用塗料に和いて, 脂肪酸の種類による電 着性抢よび乾操塗膜の性状を調べると共に, 橋カケ㶡として同時に混合使用した水溶性フェノ 一ル樹脂が，この脂肪酸変性エポキシ樹脂リン酸エステルと水溶液中での電着速度が同一であ るか否かについて検討した。

その結果, 脂肪酸としては C-18 の不飽和脂肪酸が良好であること, この合成物と水溶性フ ェノール樹脂の 2 成分混合水溶液に打汸る各成分の電着速度は, 電着塗膜と, 混合液組成の

I. R. スペクトルの検討からほぼ同一であると考光ることができた。

またりノール酸変性エポキシ樹脂リン酸エステル 5〜6 部に, 水溶性フェノール樹脂を 4〜 5 部混合して得た電着叙膜は, 耐沸騰水性が 50 時間以上安定であった。

\section{本文}

著者らは前報で1)エピクロルヒドリンージフェニロー ルプロパン系のエポキシ樹脂（分子量約 500 のもの）の 脂肪酸変性りン酸エステルが, 高防食性の電着用プライ マーとしてきわめて有望であることを報告した。

本報では変性のための脂肪酸の種類による電着性拉よ びその塗膜の性状の差異についてと, 橋カケ用樹脂とし て水溶性フェノール樹脂を混合して使用した場合に, こ の合成物と, 水溶性フェノール樹脂との軟鋼板への電着 速度が同一でないと, 実用性がないので, これらの関係 について検討した結果を述べる。

\section{実 験 の 部}

\section{1) 原 料}

エポキシ樹脂；シエル化学社製エピコート樹脂＃ 834 を使用した。エポキシ酸素=6.2 (塩酸ージオキサン法), エポキシ当量 $=260$ (エポキシ酸素よりの計算値), 見力 ケの分子量 $=520$ (エポキシ酸素よりの計算值)

脂肪酸; 市販の化学用を使用した。性状を表-1 に示 す。

2）脂肪酸変性エポキシ樹脂リン酸エステルの合成

エポキシ樹脂粉末 $100 \mathrm{~g}$ と, 脂肪酸とを $\mathrm{N}_{2}$ ガス導入 管, 温度計, かきまぜ機, 冷却管を持つ四つ口丸底フラ

昭 40.7. 26 受理

* 第 1 報本誌 38 [7] 288 296 (1965)

**大阪 $\square$ ス (株) 東京研究所

東京都大田区蒲田 4-1-8
表-1

\begin{tabular}{|c|c|c|c|}
\hline & & 中 和 価 & ヨウ素価 \\
\hline $\mathrm{C}_{12}$ & ラウリン 酸 & $279(281)$ & $2(0)$ \\
\hline $\mathrm{C}_{16}$ & パルミチン酸 & 218 (219) & $2(0)$ \\
\hline $\mathrm{C}_{18}$ & ステアリン酸 & 199 (198) & $3(0)$ \\
\hline $\mathrm{C}_{18} \mathrm{~F}_{1}$ & オレイン酸 & 201 (199) & $93(91)$ \\
\hline $\mathrm{C}_{18} \quad \mathrm{~F}_{2}$ & リノ一ル酸 & $202(201)$ & $183(181)$ \\
\hline $\mathrm{C}_{18} \mathrm{~F}_{2}$ & 脱水ヒマシ油酸 & 201 & 168 \\
\hline
\end{tabular}

（）内は計算值を示す。

スコ中に入れ， $\mathrm{N}_{2}$ ガスを $30 \sim 40 \mathrm{cc} / \mathrm{min}$ の流速で吹込 みつつ，かきまぜながら $210 \sim 220^{\circ} \mathrm{C}$ に加温してェステ 儿化を行なった。内容物の酸価が 3 以下となった時温度 を下げ，50C で約同量のアセトンを加えて溶解し，約 $50^{\circ} \mathrm{C}$ に保ちつつリン酸を加えたのち，2 時間かきまぜ てリン酸エステルとした。

ついで減圧下で加温して大部分のアセトンを留去し, さらに未反応のリン酸を除去するべく水洗し, 洗液がリ トマス試験紙で中性となるまで反復した。のち減圧下に 加温して水分を完全に除いて白色飴状の脂肪酸変性工ポ キシ樹脂リン酸エステルを得た。これらの配合量と生成 物の性状を表-2 に示す。

かくして得られた合成物は次にトリエタノールアミン で弱アルカリ性とし，水溶化し，不揮発物量 10，30\% とした。その性状を表-3 に示す。

\section{3）水溶性フェノール樹脂}

前報1)の方法によって得たものを用いた。

\section{4）電着性について}

16 [2] 
表-2 原料の配合量および生成物の性状

\begin{tabular}{|c|c|c|c|c|c|c|c|c|c|c|c|}
\hline & & $g / x$ & ゚゚キ & 樹胒 & 100 & $\mathrm{~g}^{(1)}$ & & & 生成物 & 刀 性 & \\
\hline & & 脂 & & 肪 & 酸 & & 85 & 脂肪酉 & ーエポ & & \\
\hline & $\frac{\mathrm{C}_{12}}{\overline{7}}$ & $\mathrm{C}_{16}$ & $\begin{array}{c}\mathrm{C}_{18} \\
\pi\end{array}$ & $\begin{array}{c}\mathrm{C}_{18} \\
\text { オ }\end{array}$ & $\mathrm{C}_{18}$ & $\begin{array}{l}C_{18} \\
\text { 脱 }\end{array}$ & $\%$ & $\begin{array}{l}\text { キシ } \\
\text { ステ }\end{array}$ & $\begin{array}{l}\text { 脂のエ } \\
\text { 化物 }\end{array}$ & 最終 & 生成物 \\
\hline & $\begin{array}{c}\text { ウ } \\
\text { リ } \\
\text { ソ } \\
\text { 酸 }\end{array}$ & $\begin{array}{c}\text { ミ } \\
\text { チ } \\
\text { ン } \\
\text { 酸 }\end{array}$ & 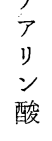 & $\begin{array}{c}V \\
1 \\
\text { ソ } \\
\text { 酸 }\end{array}$ & $\begin{array}{l}\text { J } \\
1 \\
\text { ル } \\
\text { 酸 }\end{array}$ & $\begin{array}{l}\text { 七 } \\
\checkmark \\
\text { シ } \\
\text { 油 } \\
\text { 酸 }\end{array}$ & $\begin{array}{c}\text { リ } \\
\text { ソ } \\
\text { 酸 }\end{array}$ & 酸価 & $\begin{array}{r}\text { エポキ } \\
\text { シ酸素 } \\
(2) \\
(2)\end{array}$ & 酸価 & $\begin{array}{l}\text { エポキ } \\
\text { シ酸素 } \\
\text { (2) }\end{array}$ \\
\hline 1 & 38 & - & - & - & - & - & 22 & 2.1 & 2. 2 & 61 & 0.1 \\
\hline 2 & - & 49 & - & - & - & - & 22 & 1.5 & 2.0 & 52 & 0.1 \\
\hline 3 & - & - & 54 & - & - & - & 22 & 1.3 & 2.0 & 64 & 0.1 \\
\hline 4 & - & - & - & 54 & - & - & 22 & 1.9 & 1.9 & 61 & 0.0 \\
\hline 5 & - & - & - & - & 54 & - & 22 & 1.3 & 1.9 & 63 & 0.0 \\
\hline 6 & - & - & - & - & - & 54 & 22 & 2.0 & 2.0 & 67 & 0.3 \\
\hline
\end{tabular}

（1）モル比は $1: 1: 1$ である。

（2）塩酸一ジオキサン法によって測定

表-3 合成物水溶液の性状

\begin{tabular}{|c|c|c|c|c|c|c|c|}
\hline \multirow{2}{*}{ No. } & \multirow{2}{*}{$\mathrm{pH}$} & \multicolumn{2}{|c|}{$10 \%$} & 液 & \multicolumn{2}{|c|}{$30 \%$} & 液 \\
\hline & & 観 & 粘度** & 保存性 & 観 & 粘度** & 保存性 \\
\hline 1 & 7.5 & 乳白半透明 & $A>$ & 良 & 乳白半透明 & $\mathrm{G}-\mathrm{H}$ & 良 \\
\hline 2 & 7.5 & "1 & $A>$ & 良 & "I & $\begin{array}{l}\text { カンテ } \\
\text { ソ状 }\end{array}$ & 良 \\
\hline 3 & 7.4 & 11 & $A>$ & 良 & " & $\prime \prime$ & 良 \\
\hline 4 & 7.5 & "1 & $A>$ & 良 & "I & $\mathrm{J}$ & 良 \\
\hline 5 & 7.4 & $\prime \prime$ & $A>$ & 良 & $\prime \prime$ & I & 良 \\
\hline 6 & 7.4 & "I & $A>$ & $\begin{array}{l}12 \text { 日で } \\
\text { 分離 }\end{array}$ & "I & $\mathrm{L}$ & $\begin{array}{l}4 \text { 日で } \\
\text { 分離 }\end{array}$ \\
\hline $\begin{array}{l}\text { 水溶性 } \\
\text { フェフ } \\
-ル \mathrm{R}\end{array}$ & $8.5^{*}$ & $\begin{array}{l}\text { 乳白褐色 } \\
\text { 半透明 }\end{array}$ & $A>$ & 良 & $\begin{array}{l}\text { 乳白褐色 } \\
\text { 半透明 }\end{array}$ & B & 良 \\
\hline
\end{tabular}

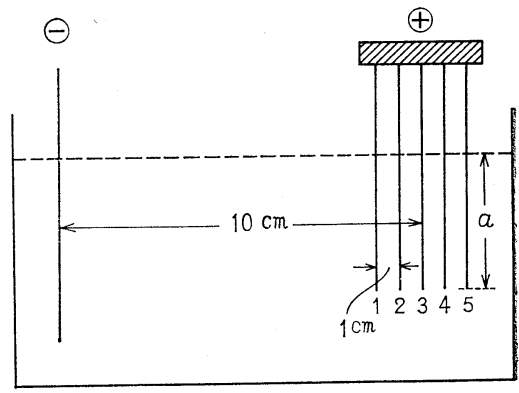

$a=25 \times 50 \times 0.5 \mathrm{~mm}$

図-1

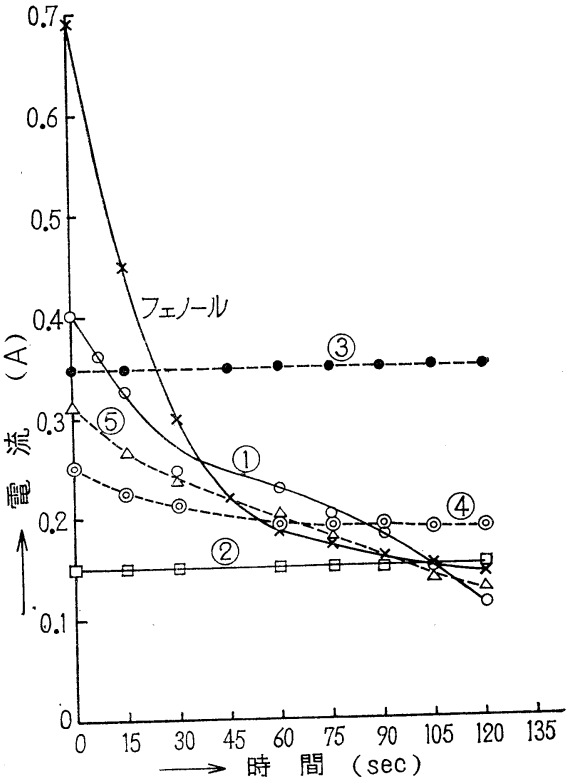

図-2

* 8.5 以下では水溶性が不良, 中和剂はアンモニア水 ** ガードナー值 $\left(25^{\circ} \mathrm{C}\right)$

実験装置は前報1) と同一のものを使用した。

4-1) スローイングパワー性

測定方法とては，パイプを用いる方法2)など種々のも

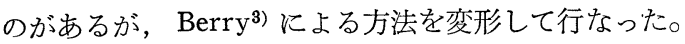
すなわち図-1のように，軟鋼板試験片 5 枚を $1 \mathrm{~cm}$ の間 隔に垂直に並べ，各々は電気的に連結する。3枚目の試

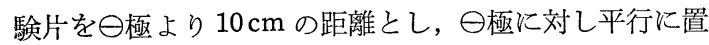
く。直流荷電を $33 \mathrm{~V}$ とし, 2 分間通電して電着させ, つぎに蒸留水で各試験片を十分に洗浄したのち, $150^{\circ} \mathrm{C}$, 30 分間加熱乾燥を行なった。

測定結果を 表-4 に，その時の電流変化を図-2に示し た。

表 4 亿示した実験結果から，スローイングパワー性の 良好なのは, No.1 のラウリン酸変性, No. 4 のオレイ
ン酸変性拈よび No. 5 のリノール酸変性のものと, 水溶 性フェノール樹脂であった。しかしラウリン酸変性によ もるものは，この単独では塗膜の乾燥性は悪く，また 水溶性フェノール樹脂による乾燥塗膜は, 耐水性, ソル トスプレーの試験結果は悪いから，結局オレイン酸抏よ び，リノール酸変性のものが良好といえる。

\section{4-2) $\mathrm{pH}$ による影響}

電着溶液の $\mathrm{pH}$ と, 付着量, 塗膜の外観, クーロン效 率等の関係について，リノール酸変性によるもの（No. 5）を用いて調べた。結果を表 5-に，その時の電流変化 を図-3 に示す。

表-5 の実験結果によれば，pH の増大に伴なって塗膜 の付着量は減少し, クーロン効率は低下している。また 焼付ケ塗面の状態は, $\mathrm{pH} .7 .0$ 以下ではオレンジピー ルとなり，8.7 以上では不均一になる。好ましい結果が 
表-4 合成物のスローイングパワー性

\begin{tabular}{|c|c|c|c|c|c|c|c|c|c|}
\hline \multirow{2}{*}{ No. } & \multirow{2}{*}{ 付着量 } & \multicolumn{5}{|c|}{ 試 験 片 の No. } & \multicolumn{3}{|c|}{ 乾燥 (焼付ヶ) 塗膜 } \\
\hline & & 1 & 2 & 3 & 4 & 5 & 色調 & 塗面 & \begin{tabular}{|l} 
乾燥 \\
状態
\end{tabular} \\
\hline \multirow{2}{*}{1} & $\mathrm{~g} \times 10^{-2}$ & 2.4 & 3. 0 & 2.8 & 2.8 & 3.0 & \multirow{2}{*}{$\begin{array}{l}\text { ほと } \\
\text { えど } \\
\text { 無色 }\end{array}$} & \multirow{2}{*}{ 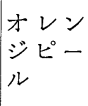 } & \multirow{2}{*}{$x$} \\
\hline & $\%$ & 84 & 108 & 100 & 100 & 108 & & & \\
\hline \multirow{2}{*}{2} & $\mathrm{~g} \times 10^{-2}$ & 13.7 & 5.6 & 3.5 & 2.1 & 3.0 & \multirow{2}{*}{ "I } & \multirow{2}{*}{  } & \multirow{2}{*}{$\times$} \\
\hline & $\%$ & 246 & 100 & 63 & 37 & 54 & & & \\
\hline \multirow{2}{*}{3} & $g \times 10^{-2}$ & 22.4 & 5.4 & 4. 0 & 2.9 & 3.2 & \multirow{2}{*}{ "I } & \multirow{2}{*}{ 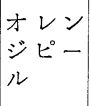 } & \multirow{2}{*}{$x$} \\
\hline & $\%$ & 296 & 71 & 53 & 38 & 42 & & & \\
\hline \multirow{2}{*}{4} & $\mathrm{~g} \times 10^{-2}$ & 2.4 & 2.5 & 2.3 & 2.0 & 2.5 & \multirow{2}{*}{ ビ黄色 } & \multirow{2}{*}{ 良 } & \multirow{2}{*}{ 良 } \\
\hline & $\%$ & 103 & 107 & 98 & 85 & 107 & & & \\
\hline \multirow{2}{*}{5} & $\mathrm{~g} \times 10^{-2}$ & 2.7 & 2.5 & 2.4 & 2.5 & 2.7 & \multirow{2}{*}{ ビ黄色 } & \multirow{2}{*}{ 良 } & \multirow{2}{*}{ 良 } \\
\hline & $\%$ & 107 & 98 & 90 & 98 & 107 & & & \\
\hline \multirow{2}{*}{6} & $\mathrm{~g} \times 10^{-2}$ & 2.8 & 2.0 & 1.9 & 1.9 & 2.2 & \multirow{2}{*}{ ビ黄色 } & \multirow{2}{*}{ 良 } & \multirow{2}{*}{ 良 } \\
\hline & $\%$ & 129 & 93 & 88 & 88 & 102 & & & \\
\hline \multirow{2}{*}{$\begin{array}{c}J= \\
J \\
\mathrm{R} \\
\mathrm{R}\end{array}$} & $\mathrm{g} \times 10^{-2}$ & 3.5 & 3.2 & 3.0 & 3.0 & 3.0 & \multirow{2}{*}{ 褐色 } & \multirow{2}{*}{ 良 } & \multirow{2}{*}{ 良 } \\
\hline & $\%$ & 111 & 101 & 96 & 96 & 96 & & & \\
\hline
\end{tabular}

表-5 pH の 影 響

\begin{tabular}{|c|c|c|c|c|c|c|c|c|}
\hline \multicolumn{2}{|c|}{ 項目 $\quad \mathrm{pH}$} & 6.2 & 6.9 & 7.2 & 7.6 & 8.4 & 8.7 & 9.2 \\
\hline \multirow{2}{*}{$\begin{array}{l}\text { 付 } \\
\text { 着 } \\
\text { 量 }\end{array}$} & $10^{-2} \mathrm{~g}$ & 10.0 & 16.8 & 8. 6 & 7.0 & 5.4 & 4.5 & 5.0 \\
\hline & $10^{-3} \mathrm{~g} / \mathrm{cm}^{2}$ & 1.8 & 3.1 & 1. 6 & 1.3 & 1. 0 & 0.8 & 0.9 \\
\hline \multicolumn{2}{|c|}{ 塗膜の状態 } &  & 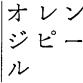 & 良好 & 良好 & 良好 & 不均 & 不均 \\
\hline \multicolumn{2}{|c|}{$ク$ ー ン 数 } & 12 & 19 & 13 & 15 & 17 & 24 & 32 \\
\hline \multicolumn{2}{|c|}{$\begin{array}{c}\text { クーロン効率 } \\
(\mathrm{mg} / \mathrm{c})\end{array}$} & 8.5 & 9 & 6.5 & 4.6 & 3.2 & 1.9 & 1.6 \\
\hline
\end{tabular}

（注） 1) 試験片は $27.5 \mathrm{~cm}^{2}, 2$ 枚の平均值, 軟鋼板 2) 電着の条件は, 極間 $11 \mathrm{~cm}$, 電圧 $33 \mathrm{~V}, 2$ 分間, 水洗を十分に行なったのち $170^{\circ} \mathrm{C}$, 30 , 分加熱乾燥した。

得られるのは，7.2〜8.4 の範团であった。

$\mathrm{pH}$ が増大すると, クーロン効率は低下するが，これ は強アルカリのために, 付着した塗膜が液中に再溶解す る結果, それに打ち勝って付着するためには, ○極に,

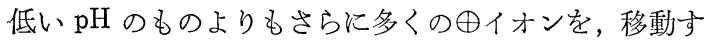
る必要があるためである。

図-3に括忷る電流変化では, pH,7.6 の場合が電流 低下が最大であり, ついで $7.2,8.4,8.7$ 順になり, 酸

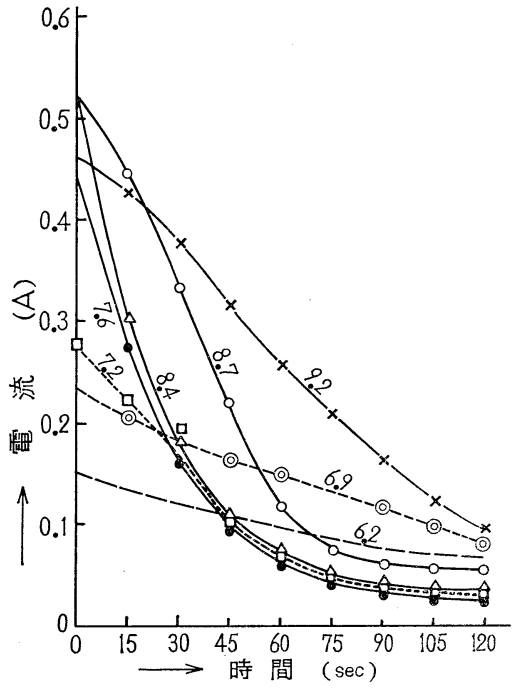

図-3

性側乱よび強アルカリ性側の 9.2 では最終電流がな括 高い。このことより, pH.7.2〜8.4のものは，軟鋼板へ の付着が均一な膜層となり，電気的に均一な絶縁膜とな るが，その他の $\mathrm{pH}$ ではピンホール，クラック等を形成 して絶縁性が弱い不均一な塗膜を作ることがわかる。

5）合成物と，水溶性フェノール樹脂との混合物にお けるおのおのの電着速度

合成物単独を用いて電着して得た塗膜では, 架橋され ていないから種々の欠点を有する。このために電着時に 合成物と同時に，一定量の架橋のための樹脂が，同一速 度で電着する必要がある。もしこれらの間の電着速度が 同一でないとするなら, 浴組成の調整が繁雑であるばか りでなく, 被塗物の塗膜性能が常に変動するから好まし くない。

合成物 No. 5 （リノール酸変性）を用い，架橋のため の樹脂として水溶性フェノール樹脂を選び，次のような 電着液を作り実験を行なった。すなわち

(A) 合成物 (No. 5$)$ の $10 \%$ 水溶液単独のもの。

（B）水溶性フェノール樹脂の $10 \%$ 水溶液単独の もの。

(C) (A), (B) 両溶液を $10 \%$ 水溶液となるよう に，樹脂分比で $1 / 1$ に混合したもの。

（D）未中和樹脂の, 合成物 (No. 5), 水溶性フェ ノール樹脂とを十分に混合し（少量のブチル セロソルブ中で）後トリエタノールアミンで ビアルカリ性にしつつ $10 \%$ 水溶液としたも の。（いずれも\%は，不揮発性物量を示す）

（C）と，（D）との方法の差は，（C）は単なる混合で 
あるから，両者の樹脂のエマルション粒子は個々に存在 し，乙たがって電着にお汀る移動は個々の粒子の移動と 考えられる。

これに対し，（D)は樹脂状に执いて混合したのち，工 マルション化したのであるから，エマルション粒子は， 合成物と, フェノール樹脂との混合粒子と考えられ, 電 着のための移動は，この混合物からなる粒子の移動と推 定できる。

これらの電着時に和ける通電時間と, 塗膜の付着量, クーロン効率の結果を表-6 に示す。

\section{表-6}

\begin{tabular}{|c|c|c|c|c|c|c|c|c|c|c|}
\hline & \multicolumn{5}{|c|}{ A（No. 5 合成物） } & \multicolumn{5}{|c|}{$\mathrm{B}\left(\begin{array}{l}\text { 水溶性フェノー } \\
\text { ル樹脂 }\end{array}\right.$} \\
\hline & 10 & 20 & 40 & 120 & 180 & 10 & 20 & 40 & 120 & 180 \\
\hline $10^{-2} \mathrm{~g}$ & 1.0 & 3.0 & 5.0 & 9.0 & 10.0 & 2.0 & 3. 1 & 4.6 & 9.3 & 12.0 \\
\hline 睡 $10^{-4} \mathrm{~g} / \mathrm{cm}^{2}$ & 1.8 & 5.5 & 9.1 & 16.5 & 18.2 & 3. 6 & 5.6 & & 17.0 & 21. 8 \\
\hline クーロン数 & 2.8 & 5.0 & 8.6 & 15.5 & 17.3 & 5.0 & 6.3 & & 19.0 & 25.0 \\
\hline クーロン効率 & 3. 6 & 6.0 & 5.8 & 5.8 & 5.8 & 4.0 & 4.9 & 4.9 & 4. 9 & 4.8 \\
\hline
\end{tabular}

\begin{tabular}{|c|c|c|c|c|c|c|c|c|c|c|}
\hline $\begin{array}{c}\text { 種類 } \\
\text { 電着時 } \\
\text { 聞 }\end{array}$ & C & 溶 & $\begin{array}{l}\text { 戈物 } \\
\text { 夜で } \\
\end{array}$ & $\begin{array}{l}\text { No. } \\
\text { J- } \\
1 / 1\end{array}$ & $\begin{array}{l}5 / \text { 水 } \\
\text { ル } \mathrm{R}\end{array}$ & $\mathrm{D}$ & & & $\begin{array}{l}\text { No. } \\
\text { ル R } \\
1 / 1 \\
\end{array}$ & \\
\hline 項日 & 10 & 20 & 40 & 120 & 180 & 10 & 20 & 40 & 120 & 180 \\
\hline
\end{tabular}


着 量 $10^{-4} \mathrm{~g} / \mathrm{cm}^{2} 3.86 .48 .616 .820 .0|4.56 .79 .1| 17.119 .1$ クーロン数 $\mid 4.25 .8$ 8.015.617.8 4.55 .98 .015 .917 .8 \begin{tabular}{l|l|l|l|l|l|l|l|l|l}
\hline クーロン效率 & 5.0 & 6.06 .0 & 5.9 & 5.9 & 5.5 & 6.36 .3 & 5.9 & 5.9
\end{tabular} $(\mathrm{mg} / \mathrm{c})$

（注）試験片はいずれも $50 \times 55 \times 0.8 \mathrm{~mm}$ の軟鋼板を 用いた。

表-6の結果によれば, 電着の初期はいずれもクーロン 効率が悪い, これは通電を始めてから塗膜が析出するま では誘導期間があるためと考えられる。

（A），（B）に护る樹脂単独の場合よりも混合した (C), (D) のものの方がいずれもクーロン効率は良くな った。また，（C)，(D) についての測定值は，ほぼ同一 であるとみなすことがでさた。

そこで, 表-7に示すような試験片を作成し, 折出塗膜 の赤外線吸収スペクトルについて検討を行なった。

すなわち分類 (A) は，この測定に用いた合成物 (No. 5 , リノ一ル酸変性物) と, 水溶性フェノール樹脂などの 単独のbのを, そのまま $100^{\circ} \mathrm{C} て ゙ 2$ 時間加熱乾燥して得 たものである。
表-7

\begin{tabular}{|c|c|c|}
\hline 分 類 & No. & 試 料 の 内 容 \\
\hline \begin{tabular}{l}
\multicolumn{1}{c}{$(\mathrm{A})$} \\
使用乙た \\
樹脂単独 \\
物
\end{tabular} & $\begin{array}{c}\mathrm{i} \\
\mathrm{ii} \\
\mathrm{iii}\end{array}$ & $\begin{array}{l}\text { 合成物 No. } 5 \text { の未中和物のフィルム } \\
\text { 合成物 No. } 5 \text { 水溶液よりのフィルム } \\
\text { 水溶性フェノール R 水溶液よりのフィ } \\
\text { ルム }\end{array}$ \\
\hline $\begin{array}{c}\text { (B) } \\
\text { 電着塗膜 }\end{array}$ & $\begin{array}{l}5 \\
6\end{array}$ & 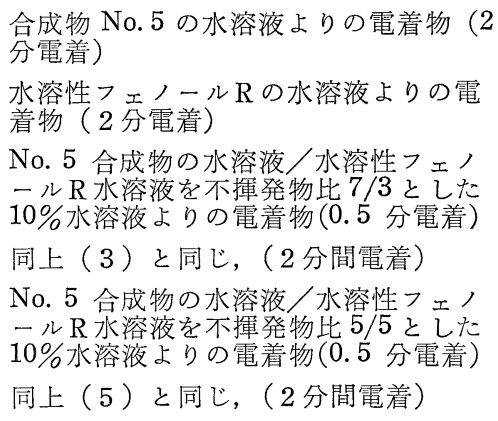 \\
\hline $\begin{array}{l}\text { 電着塗膜 } \\
\text { の混合物 }\end{array}$ & $\begin{array}{l}\mathrm{a} \\
\mathrm{b} \\
\mathrm{c} \\
\mathrm{d} \\
\mathrm{e}\end{array}$ & $\begin{array}{l}\text { 電着塗膜 }(\mathrm{B}-1) \text { と }(\mathrm{B}-2) \text { との } 8 / 2 \text { 混 } \\
\text { 合物 } \\
(\mathrm{B}-1) /(\mathrm{B}-2)=6 / 4 \text { 混合物 } \\
(\mathrm{B}-1) /(\mathrm{B}-2)=5 / 5 \text { 混合物 } \\
(\mathrm{B}-1) /(\mathrm{B}-2)=4 / 6 \text { 混合物 } \\
(\mathrm{B}-1) /(\mathrm{B}-2)=2 / 8 \text { 混合物 }\end{array}$ \\
\hline
\end{tabular}

分類（B）は，分類 (A) の (ii) 拈よび (iii) の 10 \%水溶液を作り, 各々の単独, もしくは不揮発物比で $7 / 3,5 / 5$ に各水溶液を混合して $10 \%$ 水溶液としたもの を用いて軟鋼板に電着し, $(33 \mathrm{~V})$, ついで水洗乾燥し (50 $60^{\circ} \mathrm{C}$ で真空乾燥).のち溶剂で塗膜を溶解し, 再び 乾燥してフィルムとしたものである。

分類 (C) は, (B) の方法によって得た電着塗膜 (B -1) すなわち合成物 No. 5 よりのものと，(B-2) すなわ ち水溶性フェノール樹脂よりのものを, 各々溶剤で溶出 して後真空乾乾燥して樹脂粉末として得, これを(B-1)/ $(\mathrm{B}-2)=8 / 2 \rightarrow 2 / 8$ の比に一定量を科取して混合し，つ いで，この混合物をブチルセロソルブに溶解しかきまぜ て均一としたのち, 再び真空下に加熱してフィルムとし たものである。

以上のような実験方法を考えたのは，（B）のような 万法によって得た塗膜の成分比は, 電着液中の成分比と 同一であるか否かを，（C）のような混合物と比較する ことによって間接的に知ることができると考えたからで ある。各試料についての I. R. スペクトルの結果を図-4 鿌す。

図-4に和ける実験結果より次のことが判明する。すな

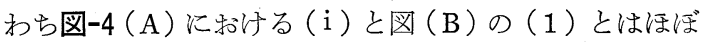
同一であることから, 電着により,アミンは合成物より単 




図-4(A)

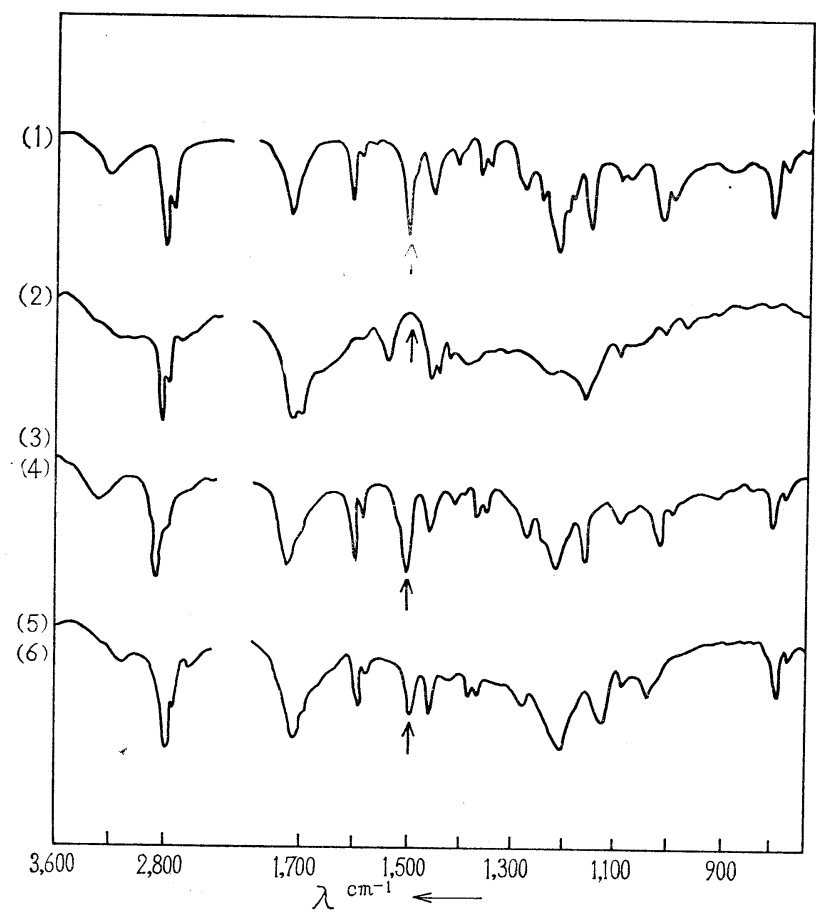

図-4（B）

吸光度のベースラインを図-5のようにするな らば，図-4 (C) そ括沙る各試料の $1500 \mathrm{~cm}^{-1}$ および $810 \mathrm{~cm}^{-1}$ の $\log I_{0} / I$ は, 図-6のよ らに直線となる。

しかし，フィルム法による場合は膜厚を一 定にして，I.R. スペクトルを測定すること は困難であるから，膜厚に比較的影響されな い比吸光度により定量できるか否かについて， 検討した結果 $2900 \mathrm{~cm}^{-1}$ の吸収に対する比 吸光度により推定できることが考学られた。 しかしこの昜合は, 図-6に打少ものりも ややバラッキが見られる。比吸光度と, 混合 比の関連図を図-7 に示した。

以上の実験結果より, 電着液の組成と電着 塗膜の組成とはほぼ同一とみなすことが可能 と考觉られる。すなわち合成物の No. 5 の 10 $\%$ 水溶液と, フェノール樹脂の $10 \%$ 水溶液 の $7 / 3$ 比混合物より得られた電着塗膜の, $1500 \mathrm{~cm}^{-1}$ に和ける $\log I_{0} / I$ は 30 秒通電の もの (B-3), 2 分間通電のもの (B-4) いず れもが約 0.4 であり，これは図-6に虬いて 直線上 $7 / 3$ の 0.4 に一致するし，また 820 $\mathrm{cm}^{-1}$ の $\log I_{0} / I$ も $0.27 \pm 0.02$ で浪泫一致 する。

また $5 / 5$ 比混合物よりの電着塗膜（B-5, B-6) む $1500 \mathrm{~cm}^{-1}$ 飞和惊 $\log I_{0} / I$ は 0.3 $\pm 0.02,820 \mathrm{~cm}^{-1}$ での $0.19 \pm 0.02$ も同様 に図-6 に特ける值に一致する。

また $5 / 5$ 比混合物よりの電着塗膜 (B-5, B-6) む $1500 \mathrm{~cm}^{-1}$ と打ける $\log I_{0} / I$ は 0.3 ; $\pm 0.02,820 \mathrm{~cm}^{-1}$ での $0.19 \pm 0.02$ も同様に 図-6 に括沙る值に一致する。

さらに図-7 に持仔る比吸光度について検 討してみるならば, (B-3, B-4) の $\log I / 0 I$ $=0.475$ 抢よび 0.48 が，ほぼ一致し，5/5。 比の (B-5, B-6) も $0.343,0.340$ となり直 線上の数字等しい。

6）合成物一水溶性フェノール樹脂におけ る配合比亡電着適性および塗膜性状の関、 係

離されるものであること。図(C)に拈けるスペクトルと, 合成物 No. 5 の $10 \%$ 水溶液（トリエタノールアミン

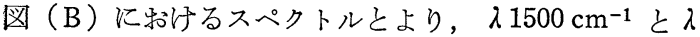
$=810 \mathrm{~cm}^{-1}$ との吸光度は, 合成物 (No. 5) と水溶性フ ェノール樹脂の混合比に相関関係があることを見出した。 すなわち，1500 $\mathrm{cm}^{-1}, 810 \mathrm{~cm}^{-1}$ に和ける吸收に和いて, 中和物, $\mathrm{pH}=7.4)$ と, フェノール樹脂 $10 \%$ 水溶液 （アンモニア水中和物, $\mathrm{pH}=8.5$ ) との種々の混合液に. よる電着性と，燒付ヶ塗膜の性状について検討した。結 果を表-8 に示す。またこの時の電流変化の一部を図-8; 

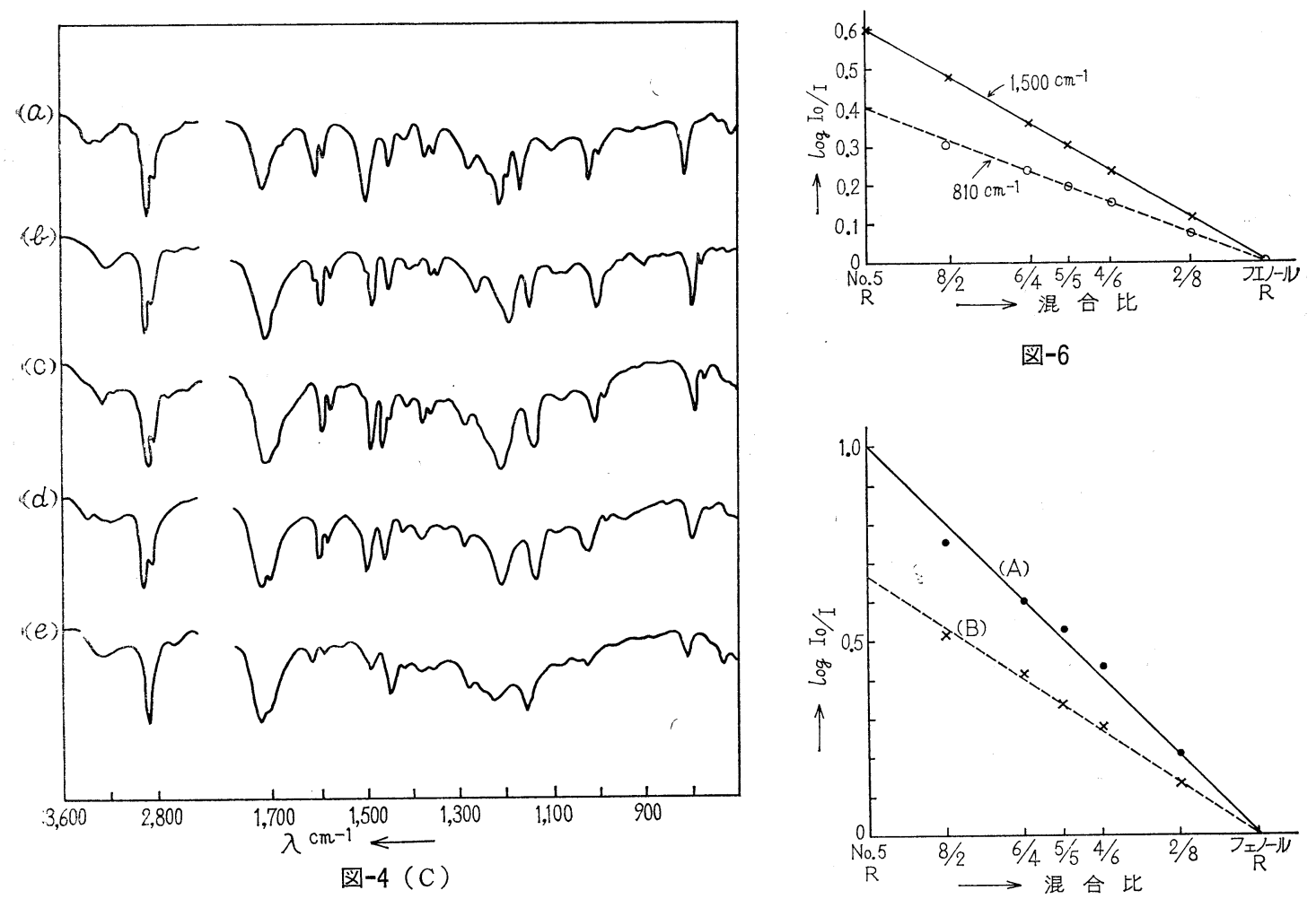

図-6

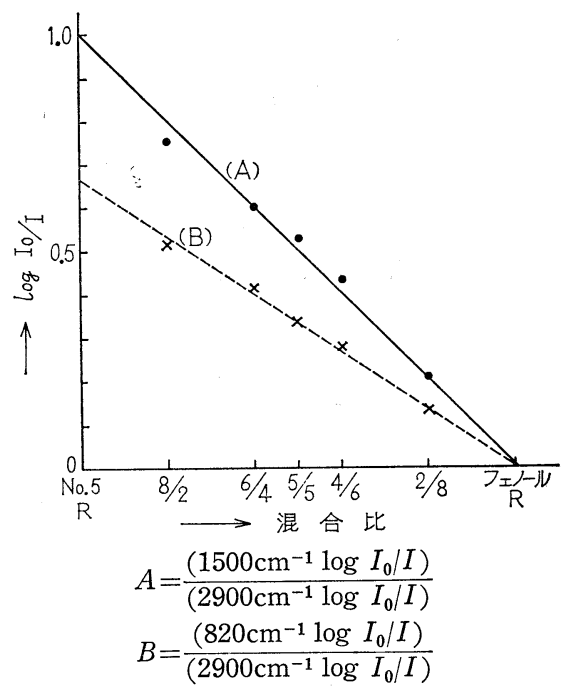

図-7

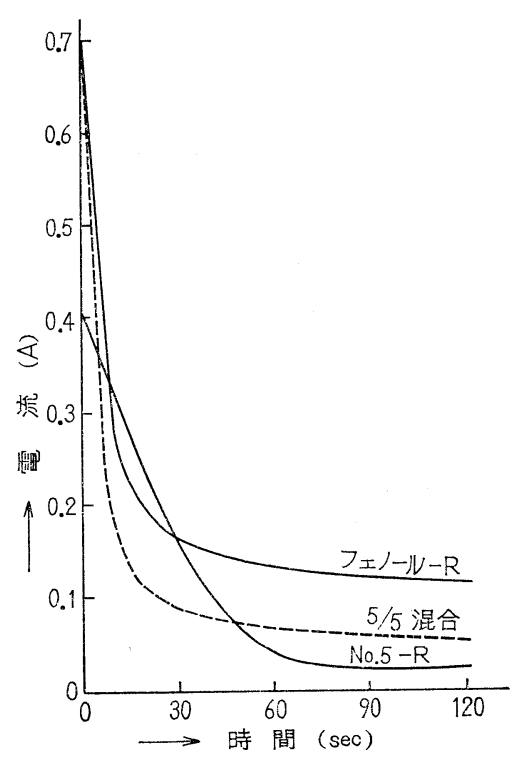

図-8 
表-8 試験片は軟鋼板 $0.8 \mathrm{~mm}$ 厚

\begin{tabular}{|c|c|c|c|c|c|c|c|}
\hline $\begin{array}{l}\text { 合成物 No. } 5 \text { / } \\
\text { フェール樹脂 }\end{array}$ & $10 / c$ & $8 / 2$ & $6 / 4$ & $5 / 5$ & $4 / 6$ & $2 / 8$ & $0 / 10$ \\
\hline 付着量 $\left(10^{-4} \mathrm{~g} / \mathrm{cm}^{2}\right)$ & 15 & 15 & 16 & 15 & 16 & 16 & 15 \\
\hline$(\mu)$ & 13 & 13 & 14 & 13 & 14 & 14 & 14 \\
\hline クーロン効率 $(\mathrm{mg} / \mathrm{c})$ & 7 & 8 & 8 & 8.5 & 8 & 6.5 & 5 \\
\hline
\end{tabular}

膜 抵 抗* $(\mathrm{k} \Omega)(0.08)(0.07)(0.06)(0.05)(0.05)(0.05)(0.05)$

膜 抵 抗* ${ }^{*}(\mathrm{k} \Omega)$ 1.6 1.51 .10 .650 .650 .550 .3



衝撃 (1kg-50cm)

描 画 A $A$ A

ゴ バ ソ 目 $100 / 100 / 100 / 100 / 100 / 100 / 100 /$



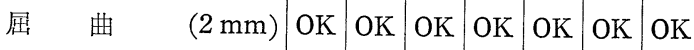

エリ ク セ $ン ~ 8 \mathrm{~mm}<8 \mathrm{~mm}<8 \mathrm{~mm}<8 \mathrm{~mm}<8 \mathrm{~mm}<8 \mathrm{~mm}<7 \mathrm{~mm}<$

\begin{tabular}{lll|l|l|l|l|l|l|l} 
沸 騰 & 水 & $(\mathrm{hr})$ & 13 & 15 & $50<50<$ & 8 & 5 & 1
\end{tabular}

\begin{tabular}{ll|l|l|l|l|l}
$10 \%$ カ性ソーダ水 $(\mathrm{h})$ & $50<50<30$ & 20 & 10 & 1 & 0.5
\end{tabular}

注 (1) 電圧, $33 \mathrm{~V}, 20^{\circ} \mathrm{C}, 2$ 分間の通電

(2) 暁付ケは $170 \sim 80^{\circ} \mathrm{C} 30$ 分

(3) *最終 (2 分後) の膜抵抗, 液の抵抗は一定と

して（）内に示した。
に示す。

表-8 の結果より耐沸騰水は合成物／フェノール樹脂 の比が $6 / 4$ あるいは $5 / 5$ のものがよいが, 耐アルカリ 性は, フェノール樹脂の混入量が増加するに従い悪くな った。

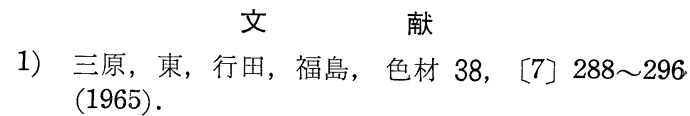

2) S. W. Gloyer et al., Offic. Dig., 37, 113 (1965).

3) J.R. Berry, Paint Tech., 27, [12], 13 (1963).

(1965 年 4 月 5 日, 日本化学会第 18 年会にて講演， 関西大学)

\section{色 材 協会誌 39 巻 3 号 (予告)}

報文

新黄色アゾ顔料の研究（第 2 報）

·田中幸蔵，萩野谷稔，阪井英彦

(大日本インキ化学工業(株))

アルキド樹脂皮膜の網目構造 高 橋 誠一

(大日本インキ化学工業(株))

キリ油変性キシンン樹脂皮膜の粘弾性質 千葉繁彦, 黄 慶 雲 (日本研紙(株)，日本瓦斯化学工業(株)）

資 料

フタロシアニン系顔料（その 4) 橋 爪清 （東洋インキ製造(株)） 電子写真黠書方法について 脇本三郎, 継国英義, 鎌田賢二

\section{色材サロン} (大日本塗料(株))

塗料の国アメリカ留学記 足田 淳 (日本油脂(株))

文

献 